\title{
RECENT PROGRESS IN EUROPEAN COUNTRIES IN WORKMEN'S COMPENSATION.
}

\author{
By Henry J. Harris, Ph.D., \\ Bureau of Labor, Washington, D. C.
}

The most conspicuous feature of the continental legislation relating to compensation for industrial accidents has been its frequent change to adapt it to the changes in industrial organization which the development of the last century has brought about. Thus at the close of the Napoleonic wars, or approximately Ioo years ago, we find in continental Europe two industries in which the ordinary rules of the liability of the employer for injuries to his workmen did not apply; these were navigation and mining. In both of them the employer was required to provide for accidental injuries on a different and more liberal scale than prevailed in other lines of employment. Mining and navigation possess two characteristics which distinguish them from other industries; in the first place, they are naturally hazardous, and second, the safety of the employee depends to an unusual degree on the skill and care of the one directing the work and on the skill and care of his fellow workmen. These two industries are among the first examples of large-scale industries to be developed, and it is worthy of note that the leading nations of Europe found it necessary to modify the ordinary doctrines of employers' liability and to devise special legal institutions to provide for the conditions peculiar to those industries. It should also be noted that in mining and navigation the injured employee was not required to bring suit in a court of law to obtain the compensation for his injury, but the law required the owner of the undertaking to provide in advance a special fund from which the benefits for this purpose were paid. Thus, even at the beginning of the modern industrial era, the rules at present regulating the liability of the employer in the United States had already been found inadequate in two important industries in Europe and a crude system of accident insurance had been substituted.

In the thirties a new industry-perhaps the most important of modern power-using industries-was created, namely, the railroad (246) 
industry. It likewise possessed the characteristics of a high trade risk and the dependence of the employee on the skill and care of the one directing the work and of the fellow workman. The problem of the injured workman came up at once and Prussia cut the Gordian knot by enacting its law of 1838 , which put the employee in practically the same position as the passenger as far as damages for injuries were concerned; to provide the compensation called for under this law, the railroads promptly created insurance or relief funds modeled after the miners' funds. Thus, in a third largescale industry the liability rules were found wanting and were discarded for a form of insurance. Other states on the continent of Europe also modified the liability doctrine to fit conditions in the railroad industry, but in marked contrast, both England and the United States retained the old liability rules.

The next break with the old liability rules came after the factory system began to spread over the continent, or in other words as soon as large-scale industries began to be frequent. The first instance came late in the sixties and early in the seventies when three states, Bavaria, Baden, and Württemberg authorized local governments to make deductions from the earnings of factory employees and similar workmen, to be paid into the local treasuries and used as an insurance or relief fund for the benefit of factory workmen who were disabled either by sickness or accident. As the deductions were small, they were in many cases paid by the employers instead of being taken from wages as the law permitted. While not as sharp a break with the liability traditions as the Prussian railroad law of $\mathbf{1} 838$, it was nevertheless a recognition of the failure of the liability principles to meet the needs of the newer industrial conditions.

The importance attached to this subject is shown by the fact that one of the first laws enacted by the newly created empire of Germany was the liability law of $\mathrm{I} 87 \mathrm{I}$; this admirable piece of legislation is still in force and probably represents the highest development of the method of compensating industrial accidents on the basis of fault. Ten years' experience under this law was sufficient however to convince both employers and workmen that legislation which made the granting of compensation dependent on the proof of negligence would do no more than serve as a background for-a system adapted to the industrial conditions of the time. The prob- 
lem became particularly urgent in Germany about I880, because the increasing cost of living at that time made the additional burden of carrying the cost of the accidents a matter of serious importance to the workmen. In passing, it may be remarked that relieving the workmen of the cost of carrying disability caused by accidents is one method of decreasing the cost of living, and if the cost of the accidents is defrayed by a system of insurance at the expense of the consumers the advantages are proportionately increased because of the extremely small amount borne by each person taxed.

The experience of the mining and railway funds provided the German investigators with a basis on which to found their new system of accident relief. The laws of Germany providing for the national compulsory sickness and accident systems were enacted in the early eighties and since then the leading industrial countries of the continent have been following the example of the Germans. The importance of the subject of social insurance is best indicated by the fact that in practically every year since 1883 , the imperial legislature of Germany has had some phase of this subject under discussion.

It is worth while to repeat this phase of European experience since it emphasizes two points; first, that the plan of compensating industrial accidents by determining who was at fault and assessing the cost on the negligent party, has never applied to all industries, and in fact has long been discarded in those industries which most closely resemble the industries of the present day; second, that every system of accident compensation which has yet been devised needs constant revision in order to be adjusted to the changing methods of conducting industries under modern conditions. The same is true of course of other industrial legislation. The decisions of American courts seem, in many instances, to assume that the negligence method of compensating accidents is essential to the maintenance of the existing social structure, and under this assumption the courts have applied the negligence rules without any modification to industries such as mining, with the resulting confusion and absurdities which have so frequently been pointed out in recent discussions.

As one state of the United States (Washington) has already adopted a system of government insurance, while two states (Montana and Maryland) have in operation compulsory insurance funds 
for the mining industries, and it is believed that other states will eventually adopt the same plan, it will be of interest to mention the points on which special progress in Europe has been made in the last ten years.

Occupations. Since 1900 , the most important advance in Europe has been the extension of the insurance to wider groups of employees. The usual plan has been to first include the industries with a high trade risk, and later to extend the list of industries. The British law of I906 has gone farthest in this respect by including "any employment"; the French law includes the usual industries together with mercantile industries. In the important industrial countries the law now includes all the leading industries.

General administration. The most successful administration of the insurance laws has occurred in the countries where the interested parties, the employer and the workman, have an important part in enforcing the laws. Austria, Hungary, Luxemburg and Germany have placed the administration of the insurance laws in the hands of employers' associations, acting under the supervision of the government officials. In some countries boards or councils, which include employers and workmen, administer the government insurance banks, while in other countries permanent councils, including representatives of these two parties, keep in touch with the development of the movement and make recommendations for improvements.

Financial administration. Europe now offers us almost every conceivable method of providing workmen's insurance; Norway has a state insurance bank in which the employers are compelled to insure, in other words, a government monopoly; Great Britain permits the employer to insure or not, as he pleases, but if he desires to insure, the private companies are his only resource; Germany, Austria, and other countries compel those who pay for the insurance to provide it themselves on the mutual plan; in other countries we find a state institution offering insurance in competition with private insurance companies or with employers' mutual insurance societies. During the last ten years, the trend of opinion has been towards compulsory insurance in prescribed institutions. This movement towards compulsory insurance is based wholly on the desire to secure the safest and cheapest form of insurance; it is obvious that the best insurance results are obtained by including the 
largest possible numbers, and compulsory insurance offers the only method of securing this result. It is now generally admitted that mutual organizations of the employers, such as the Austrian and German organizations, provide the most economical machinery for placing the accident relief in the hands of the injured persons. The least economical method is the plan of allowing the employer to insure in private insurance companies competing with each other, as is the case in Great Britain. Two forms of insurance may be differentiated, first compulsory, and second voluntary. On this basis, the plans in use in Europe at present are as follows:

\section{Compulsory Insurance}

Two forms of compulsory insurance are differentiated-compulsory insurance and compulsion to insure; one enforcing compulsory insurance in prescribed institutions, the other enforcing the obligation to insure, but leaving free the choice of the insurance institution.

A. Compulsory insurance in prescribed institutions.

I. In a government institution with a monopoly of insurance:

Norway, one state insurance bureau for all industries.

This is the only country where the entire insurance is concentrated in one government office.

2. In employers' compulsory mutual associations, controlled by the state.

$a$. Organized on territorial lines.

(I) Luxemburg, one institution, for all industries.

(2) Hungary, two institutions-one for Hungary and one for Croatia-Slavonia, including all industries.

(3) Austria, seven institutions, the whole country being divided into seven districts for all industries, in addition to which there are separate institutions for railroads and mining.

$b$. Organized on industry lines.

(I) Germany, 66 industrial institutions, each covering the entire country for one group of industries, except that some industries have several associations, each covering a specified area; in addition there are 48 agricultural institutions. 
(2) Greece and New South Wales, where the laws apply to mining only; each country has a special miners' fund.

B. Compulsory insurance with choice of insurance institutions.

I. Private companies or mutual associations with state institutions competing.

a. Italy has the National Industrial Accident Insurance Institution; except that for navigation and for the Sicilian sulphur mines, compulsory mutual associations have been created by special legislation.

b. Netherlands has the Royal Insurance Bank. The employers may insure in private insurance companies or may be permitted to carry their own insurance, but all compensation is paid by the Royal Insurance Bank which deals with the employer or insurance company.

2. Private companies or mutual associations without state institution competing.

Finland, except that for seamen a special compulsory employers' mutual association under strict government control has been established by special law.

\section{Voluntary Insurance}

A. Private companies or mutual associations with state institution competing.

I. Sweden, with State Insurance Institute.

2. France, with National Accident Insurance Fund, which, however, is not permitted to provide insurance against temporary disability. Compulsory insurance is provided for seamen in a special government institution.

B. Private companies or mutual associations without state competition.

I. Belguim, while the law specifies that the National Retirement Fund must provide accident insurance, this provision of the law has never been put into operation.

2. Denmark, where insurance is voluntary, except that the law requires compulsory insurance of seamen, either in mutual associations or in insurance companies, and where a state institution exists for voluntary insurance of fishermen and seamen not covered by the compulsory law. 
3. Great Britain and the British colonies.

4. Russia, except for compulsory insurance of miners employed by the state or the Crown.

5. Spain.

Methods of guaranteeing insurance payments. Wherever there is compulsory insurance in prescribed institutions controlled by the state, there is, of course, no question as to the security of payments. Such is the case in Norway, where a government bureau provides the insurance. In Germany, Austria, Hungary, Luxemburg, and Netherlands the law either specifically states or implies the guarantee of the solvency of the institutions providing the insurance. In Netherlands the injured workman is protected by the equivalent of insurance in the Royal Insurance Bank, irrespective of the institution in which the employer carries the insurance; the uninsured employer and the private insurance companies are required to give satisfactory guarantees to the Royal Insurance Bank. In Greece the payments are guaranteed by the national miners' fund.

The second method of state guarantee is by a special national fund, from which the compensation is paid in cases of insolvency either of the employer or of the insurance carrier. The sources of revenue of these funds show considerable differences. In Italy, notwithstanding the system of compulsory insurance, a fund has been organized under the supervision of the Government Bank of Deposits and Loans; supported by fines for noncompliance with requirement to insure, or other fines, and by the compensation due in fatal cases but not paid because of absence of survivors. In France the guarantee fund is managed by the National Old Age Retirement Fund and is supported by special taxes upon all employers covered by the act, but this fund guarantees pension payments only while compensation for temporary disability is secured by a preferred claim on the assets of the employer. In Belgium the guarantee fund is managed by the National Retirement Fund and is supported by a tax levied only upon those employers who do not carry insurance.

Where no state guarantee exists guarantees must be exacted from insurance companies or from the individual employer. Wherever insurance is either voluntary or there is a choice of insurance institutions, the government protects the insured employee by requiring the insurance company to maintain proper reserves or to 
make guarantee deposits with the government, or by both methods combined.

In the case of uninsured employees, their interests are usually protected by giving them a preferred claim upon the assets of the employer. In certain countries, where there is no compulsory insurance, the employer is not permitted to carry the liability for continuous payment of pensions in cases of death or permanent disability, but must provide for such payments through insurance institutions.

In Belgium both reserves and guarantee deposits are exacted; in addition the capitalized value of pensions must be deposited in the National Retirement Fund. There is, therefore, no necessity for giving the injured employee a preferred claim on the assets of the employer.

Finland requires the payment of the capitalized value of the pension to an insurance company in cases where no insurance has been taken. The guarantee of the pension payments of the uninsured employer is limited to a preferred claim upon his assets in case of insolvency in the following countries: Denmark, Great Britain, Russia, Sweden and the British colonies.

In Spain both reserves and deposits are required from insurance carriers, but in case of uninsured employers no especial provision is made in case of insolvency. ${ }^{1}$

Information as to accidents. One of the very best things European experience has given $\mathbf{u s}$ is accurate information as to the trade risk in the different industries and the causes and results of industrial accidents. The recent report of the German Imperial Insurance Office is a veritable mine of information in this fieid. Some of the facts brought out by this study of the industrial accidents compensated in the year 1907 are $:^{2}$

The information relates only to serious industrial accidents, namely, those causing either disability lasting longer than thirteen weeks, or death, which were compensated in the year 1907. The much larger number of accidents causing disability of shorter duration is not included.

Expressed in terms of workmen who had been employed 300

${ }^{1}$ See also Bulletin of the United States Burenu of Labor number 90, page 719 for further discussion of this point.

"See also "Industrial Accidents and Loss of Earning Power," by Henry J. Harris in Bulletin of the United States Bureau of Labor number 92. 
days in the year, the number of persons included in this study was $8,600,000$.

About one workman out of every roo received injuries causing serious disability or death, the average rate being 9.44 per 1,000 full-time workmen.

In the period I897 to I907: death.

There has been a decrease in the rate for accidents causing

There has been a decrease in the rate for accidents causing total permanent disability.

There has been a decrease in the rate for accidents causing partial permanent disability.

There has been a marked increase in the rate for accidents causing temporary disability lasting longer than thirteen weeks.

Workmen employed in teaming, hauling, etc., have the highest accident rate; workmen engaged in the tobacco industry have the lowest accident rate.

Arranged in order, the highest coming first, the following ten industry groups show the highest accident rates: teaming and hauling, flour milling, mining, woodworking, brewing, engineering construction, inland navigation, iron and steel, express and storage, and the building trades.

Arranged in order, the lowest coming first, the following ten industry groups show the lowest accident rates: tobacco, clothing, textiles, printing, pottery, paper, glass, railways (private), chimneysweeping, and marine navigation.

The accident rate for males is higher than the rate for females.

Injuries to workmen occur with some uniformity throughout the various months of the year, with a slightly higher rate in October.

Workmen are injured more frequently on Monday forenoon and Saturday afternoon than during the rest of the week.

Workmen are injured more frequently in the latter part of the forenoon and in the latter part of the afternoon than during the rest of the day.

Of the 81,248 workmen injured, about 5 per cent were injured during the first hour that they were at work, 8.6 per cent were injured during the second hour, 9.2 per cent during the third hour, I 1.3 per cent during the fourth hour, and 12.2 per cent during the 
fifth hour, the highest for the day; for the rest of the working day the percentage is irregular.

Workmen are injured most frequently by fractures, contusions, etc., and these injuries occur most frequently to the arms and legs.

Workmen are injured more frequently if they have been employed in an establishment for but a short period of time; considering only the first year of the workman's employment in an establishment, those employed a shorter period of time are injured more frequently than those employed for a longer period.

Workmen are injured more frequently if they have been employed in an occupation for but a short period of time; considering only the first year of the workman's employment in an occupation, those employed for a shorter period of time are injured more frequently than those employed for a longer period.

Workmen are injured most frequently by working machinery (presses, lathes, looms, etc.) ; arranged in order, the highest coming first, the five most frequent causes of injury are: first, working machinery; second, collapse, fall, etc., of materials ; third, loading, unloading, etc.; fourth, falls, falling from ladders, stairs, etc.; and fifth, railway operation.

Workmen receive fatal injuries most frequently from the collapse, fall, etc., of materials; arranged in order, the highest coming first, the five most frequent causes of injury are: first, collapse, fall, etc., of materials; second, railway operation; third, falls, falling from ladders, stairs, etc.; fourth, inflammable, hot, or corrosive substances, etc.; and fifth, teaming, hauling, draying, etc.

Of the injured workmen sustaining serious injuries, about 50 per cent were still disabled to a greater or less extent at the end of five years.

Workmen injured by accidents due to the fault of fellow workmen formed 5.9 per cent, by accidents due to the fault of the employer 12.6 per cent, by accidents due to the general hazard of the industry 37.7 per cent, and by accidents due to their own fault 4I.3 per cent of all the injured persons studied. During the period 1897 to 1907 , the proportion of accidents due to the fault of the employer has decreased, that due to the hazard of the industry has decreased, while that due to the workmen's own fault and to the fault of fellow workmen has increased. 
Progress in medical treatment. One of the best features of the European experience is the demonstration that by a comprehensive plan of medical treatment, many injuries which were formerly classed as permanent disabilities, may be removed and the earning capacity of the injured person restored. In Germany special institutions for the treatment of industrial accidents have had remarkable success in removing disabilities which have heretofore been regarded as permanent disabilities. Experience has shown that where life pensions for injuries are paid, the insurance administration must adopt aggressive measures for the treatment of the injured. The lack of knowledge on the part of the workmen, the inexperience of many surgeons in general practice and it must be admitted, the occasional unwillingness of the injured person himself, makes it not only advisable, but imperative that ample control over the medical treatment of injured persons be placed in the hands of the insurance authorities.

Forms of disability other than accidental injuries. That the risks of modern industry cannot be entirely included under the term accident has been clearly shown by recent experience. This is well known in the case of workmen who handle such substances as lead, arsenic, hides which produce anthrax, as well as other well-known occupational diseases. 'Other forms of disablement due to the occupation come more slowly but cause disability no less severe than an accident. The glass and the metal grinder for instance, have death rates from lung affections much in excess of the average rate. The trade life of the miner for instance is comparatively short and the exhaustion of his working ability comes much earlier than in the case of the average workman. The cost of these disablements is an expense which Austria, France and Germany charge on the industry, although the workman and the state also contribute. In Great Britain, the disabilities due to a specified list of occupational diseases are included under accidents entitled to compensation. 